\title{
Impact of COVID-19 on wild meat trade in Nigerian markets
}

\author{
Stephan M. Funk ${ }^{1}$ ( ) ｜ Julia E. Fa $\mathbf{F}^{2,3}$ () ｜ Stephanie N. Ajong ${ }^{4}$ | \\ Edem A. Eniang ${ }^{5}$ | Daniele Dendi ${ }^{6,7,8}{ }^{-}$| Robert Nasi ${ }^{3}{ }^{\circ}$ | \\ Massimiliano Di Vittorio9 (ㅇ | Fabio Petrozzi ${ }^{10}$ @ | Nio King Amadi ${ }^{7}$ | \\ Godfrey C. Akani ${ }^{7}$ | Luca Luiselli ${ }^{6,7,8}$ \\ ${ }^{1}$ NatureHeritage, Jersey, Jersey \\ ${ }^{2}$ Department of Natural Sciences, School of Science and the Environment, Manchester Metropolitan University, Manchester, UK \\ ${ }^{3}$ Center for International Forestry Research (CIFOR), CIFOR Headquarters, Bogor, Indonesia \\ ${ }^{4}$ Department of Fisheries, Lagos State University, Ojo, Lagos, Nigeria \\ ${ }^{5}$ Department of Forestry and Wildlife, University of Uyo, Uyo, Akwa-Ibom State, Nigeria \\ ${ }^{6}$ Institute for Development, Ecology, Conservation and Cooperation, Rome, Italy \\ ${ }^{7}$ Department of Applied and Environmental Biology, Rivers State University of Science and Technology, Port Harcourt, Nigeria \\ ${ }^{8}$ Département de Zoologie et Biologie Animale, Faculté des Sciences, Université de Lomé, Lomé, Togo \\ ${ }^{9}$ Ecologia Applicata Italia, Palermo, Italy \\ ${ }^{10}$ Ecolobby, Rome, Italy
}

Correspondence

Stephan M. Funk, NatureHeritage, Jersey, Channel Islands.

Email: smf@natureheritage.org

Julia E. Fa, Department of Natural Sciences, School of Science and the Environment, Manchester Metropolitan University, Manchester M1 5GD, UK. Email: jfa949@gmail.com

Luca Luiselli, Institute for Development, Ecology, Conservation and Cooperation, Rome, Italy.

Email: 1.luiselli@ideccngo.org

Funding information

Turtle Conservation Fund; Chelonian Research Foundation; Associazione Centro Elis; Snamprogetti s.p.a.; Conservation International; Sabin Family Foundation; Mohamed Bin Zayed Species Conservation Fund; IDECC

Wild meat plays a crucial role in the food security and cash income of subsistence hunters in the tropics and subtropics in Africa, South America, and SE Asia (Coad et al., 2019; Fa et al., 2022). This meat is regularly traded in markets in many towns and cities (see Fa et al., 2019). In Nigeria, the amount of meat sold from most species crashed dramatically after the Ebola virus outbreak in 2014, highlighting the awareness of the general public of a

Daniele Dendi and Luca Luiselli are lead authors. link between disease risk and wild meat (Akani et al., 2015; Funk et al., 2021). The opportunities for zoonotic spill-over have increased in parallel with the increase of the intensity and extent of bushmeat trade over the last decades (Karesh \& Noble, 2009). The report by UNEP, International Livestock Research Institute (2020) on preventing the next pandemic lists increasing human demand for animal protein among seven human-mediated factors as the most likely driving the emergence of zoonotic diseases, which includes wild meat hunting. 
The 2020/21 COVID-19 pandemic poignantly reminds us of the social, economic, and health consequences of zoonotic diseases (FAO, CIRAD, CIFOR, WCS, 2020). "Wet" markets selling wild meat and live wildlife are presumed to have played a crucial role in increasing the risk of spill-over events from wildlife to humans (Jones et al., 2008). While the COVID-19 virus' origin remains unknown, it is believed to have resulted from a spill-over event that may have emerged in or was amplified by a wet market in Wuhan in China's Hubei province (Lu et al., 2020). The previous 2003 SARS-CoV outbreak likely originated also in Chinese markets that also offer wildlife and/or wild meat for sale (Cui et al., 2019; Guan et al., 2003; Lu et al., 2020). In such markets, large numbers of wild and domestic animals of different taxonomic origin are regularly kept in unhygienic, crammed and stressful conditions, creating perfect storms for crossspecies and zoonotic transmission, as shown in a study of SARS-CoV prevalence in civets (the most likely intermediate host) along the market chain in Guangzhou, China. Farmed civets were essentially free from SARS-CoV infection, but prevalence was $\approx 80 \%$ for animals sold in markets (Tu et al., 2004).

Countless numbers of different mammals, reptiles, and bird species are hunted to be sold in many West and Central African countries, including Nigeria (Petrozzi et al., 2016; Taylor et al., 2015). We monitored wild meat sales of antelopes (including duikers), bush pigs, carnivores (including mongooses), fruit bats, diurnal primates, large rodents (particularly grasscutters and porcupines) and reptiles (including crocodiles, snakes, tortoises and turtles) in nine markets in southern Nigeria's Niger delta before and after COVID-19. We did not observe pangolins since these are uncommon in the delta but are more frequently sold in markets east of the delta. Our nine study markets are significant concentration points for wild meat, located along main roads and near principal rivers and urban centers. These areas are heavily populated containing hundreds of villages interspersed by patches of deltaic moist and flooded forests, as well as agricultural land (for map and more details, see Funk et al., 2021). Each market had around 20-30 counters with animal carcasses displayed for sale to customers. Wild meat trade has been traditionally an important source of food and income (Fa et al., 2006; Luiselli et al., 2013). In our study, monitoring commenced in 2010. Results up to the end of 2019 in the context of the Ebola virus disease (EVD) outbreak of 2014 are presented in Funk et al. (2021). We surveyed each market about once every 10 days almost every month from 2016 onward, but less often between 2010 and 2015. In each market, we counted the total number of carcasses displayed by sellers very early in the morning when carcasses arrived and before selling started. Carcass counts were summarized over markets for each surveyed month by calculating mean numbers of carcasses per market per day in each month. Here, we report sales volumes between January 2019 and February 2020 (the preCOVID-19 phase) and between March and Dec 2020 (the COVID-19 phase). We compare sales for these periods with the pre-EVD period from 2010 to June 2014.

COVID-19 reached Nigeria on March 2020, triggering the Presidential COVID-19 Taskforce established on March 9. A travel ban and restrictions on large gatherings ensued on March 18, and lockdowns followed on March 30. A federal total lockdown in the capital and several states was extended until the end of April. Because of public resistance as a consequence of the severe socioeconomic consequences resulting from confinement, total lockdown was eased. This was replaced by overnight curfews, obligatory wearing of facemasks and hand washing, social distancing, and avoidance of crowds recommended (Ajide et al., 2020; BBC, 2021; Dixit et al., 2020). However, various states continued to impose restrictions and lockdowns in line with the rise of COVID-19. Rivers State, where our market surveys were conducted, was the state with the fifth highest COVID case rate in Nigeria (Owhonda et al., 2020). Statewide total lockdown occurred in several occasions and nighttime curfew was in force during most of 2020, preventing or impinging upon the hunting animals and movement of hunted animals to markets.

Figure 1 shows the trends of sales volumes (i.e., mean daily numbers of carcasses per market in each month) pre- and post-COVID-19 demonstrating that sale volumes decreased for all monitored taxonomic groups. Significant declining trends were observed for antelopes (MannKendall statistics for changes in time series $=-2.58$, $p=.005)$; bush pigs $(-2.4, p=.008)$; fruit bats $(-3.09$, $p=.001)$; diurnal primates $(-4.81, p<.001)$; reptiles $(-3.82, p<.001)$; and rodents $(-3.27, p<.001)$ but not for carnivores $(-1.59, p=0.056)$. These declines happened even though wild meat markets had not yet fully recovered from the dramatic reduction after the EVD outbreak in 2014 (Funk et al., 2021). Comparing the mean monthly pre-EVD, pre-COVID-19, and COVID-19 periods, sale volumes revealed the lowest values for the COVID-19 period: antelopes (4.9, 1.8, 0.9); bush pigs (not monitored, 0.9, 0.6); carnivores $(4.4,2.0,0.5)$; fruit bats (14.8, 0.7, 0.2); diurnal primates $(2.7,0.1,0.0)$; reptiles $(3.6,2.0,0.5)$; and rodents $(24.2,16.5,8.8)$. With the exception of reptiles, it is unlikely that the observed decline after the outbreak of COVID-19 resulted from overexploitation rather than disease risk. First, the decline across all species coincided with the first cases of COVID-19 reported in Nigeria. Second, after the dramatic 

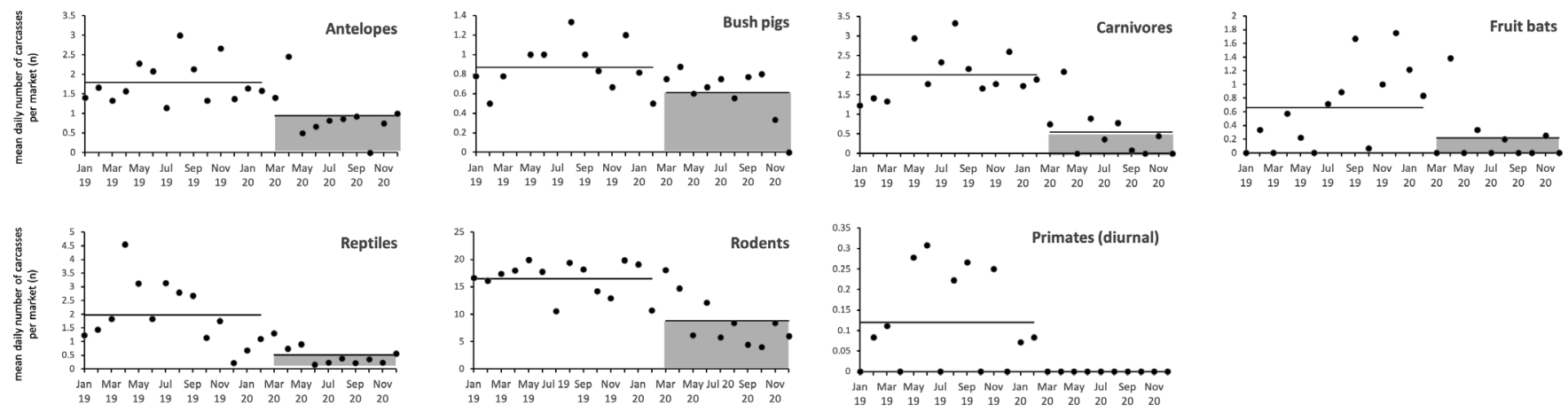

F I G U RE 1 Trends in the daily mean numbers of traded carcasses across nine bushmeat markets in southern Nigeria for January 2019December 2020, including the periods before (2019 to February 2020) and during (March-December 2020) the outbreak of the COVID-19 pandemic. The horizontal lines show the mean sales for before and during COVID-19. The COVID-19 period is highlighted in gray

collapse of wild meat sales during the EVD outbreak in 2014, ungulates, rodents, and carnivores significantly increased up to COVID-19 (Funk et al., 2021). Sales of fruit bats and primates, the species most implicated as the potential source of EVD, remained low after EVD, but declined even further after COVID-19. Only reptiles showed a different trajectory. Reptile sales declined prior to EVD, but rebounded immediately post-EVD, indicating compensation of the reduction of mammal wild meat, likely because reptiles are not implicated in EVD transmission. However, reptile sales declined after 2017, presumably as a result of population collapse and depletion. The further decline of reptiles in 2020 during COVID-19 might have been part of the long-term population decline. Estimates of population size in the Niger Delta have demonstrated heavy depletion during the last two decades for forest tortoises (Akani et al., 2018; Luiselli et al., 2016) and a number of snake species (Reading et al., 2010). Indirect evidence for crocodiles, from structured interviews, also indicates population declines in Nigeria (Eniang et al., 2020).

Wild meat sale volumes in markets may have declined because of one of several COVID-19-related reasons or a combination of these. First, many Nigerians adopted wearing of protective masks and observed social distancing immediately after the first observed cases (2020); this was despite the widespread conspiracy theories about the virus' origin and severity in Nigeria (WILDAID USA, 2021). This indicates there was a fast adoption of behavioral responses to prevent disease transmission between people by a large proportion of the population, perhaps because of prior sensitization to the risk of zoonotic diseases during EVD (Funk et al., 2021). To explore the awareness and perception of residents in Rivers State, a cross-sectional survey ( $n=1294$ persons) was conducted between mid-May and mid-June 2020, that is, in the early phase of the COVID outbreak in Nigeria
(Owhonda et al., 2020). This study demonstrated a high awareness of disease transmission between people $(87.5 \%$ of respondents affirmed that contact with infected persons can transmit the disease) and $19.4 \%$ of respondents believed that they could get infected from animals. However, only $2.8 \%$ of people stopped eating wild meat. During the later stage of COVID-19 at the end of 2020, attitudes had changed. WILDAID USA (2021) conducted a phone survey of 2000 respondents across four major Nigerian cities in late 2020, Port Harcourt in Rivers State where two of the markets surveyed by us were located in its outskirts. Against the backdrop of widespread wild meat consumption in Nigeria $(71 \%$ of respondents have consumed wild meat with $45 \%$ having consumed it within the last year), the survey demonstrated changed attitudes as $27 \%$ of respondents stopped eating and $31 \%$ ate less wild meat since the COVID-19 outbreak. These numbers were higher for those Nigerians that believe that COVID-19 is caused by wild animals (31 and 35\%, respectively) than those that do not believe this (21 and 25\%, respectively). Similarly, after the EVD outbreak, over $80 \%$ of market visitors reported that they would not eat again bats or primates because of the perceived disease risk from these specific animal groups (Funk et al., 2021). Thus, these surveys indicate that fear of disease transmission from wild animal meat likely contributed to reduced wild meat eating after COVID-19. It also means that those who were skeptical about the link between COVID and wildlife changed their wild meat consumption behavior in large numbers (46\%), possibly as a precautionary strategy because of the EVD experience or other reasons.

Second, imposed travel restrictions might have impacted the number of animals available on markets by disrupting supply chains and by changed purchasing behavior. Importantly, while EVD affected taxa differently with sales of mammals decreasing and sales of 
reptiles, which were never linked to EVD, initially increasing, COVID-19 was linked to a reduction of sales in all observed mammal and reptile taxa. Because of the concurrent decline of all taxa in wild meat marketswhether potentially linked to COVID-19 transmission, like bats, or not, like reptiles-it is likely that COVID19-related restrictions on movements had a strong impact on reduced market sales. In addition to directly disrupting supply chains, shifts in purchasing behavior might have occurred like in the case of Ebola in Sierra Leone. There, the mismatch between their own experiences and official guidance caused a mistrust in authorities, leading to the proliferation of informal networks of wild meat sales, thus circumnavigating official markets (Bonwitt et al., 2018). Informal networks might have been further supported by people's fears about buying in markets, which are typically very crowded and constitute ideal opportunities for COVID-19 transmission. Thus, changes in market sales can reflect changes in both supply-side and demand-side dynamics (McNamara et al., 2020).

In agreement with a previous observation after the COVID-19 outbreak (Meseko et al., 2020), we observed that nearly all typical wild meat types were still traded after the COVID-19 outbreak phase although primates disappeared completely. However, the presence of wild meat markets during the COVID-19 period does not necessarily point to a "thriving" business, as Meseko et al.'s (2020) isolated post-outbreak observations appeared to show without the benefit of long-term monitoring data, but a business that has been declining over time. Thus, investigations of wild meat traded during an epidemic without the benefit of long-term monitoring can result in biased interpretations of data. As shown in this study, long-term monitoring of wild meat trade is extremely important for the interpretation of ecological data when future epidemics occur.

Given the decline of wild meat sold in southern Nigerian markets caused by two zoonotic diseases, educating consumers about disease risks in these circumstances can be vital to better influence their attitudes toward wild meat consumption (Funk et al., 2021). The decline was particularly strong among young and urban people, confirming the trend observed in West African cities which observed that younger people are particularly opposed in eating wild meat compared to older people independent of gender and country (Burkina Faso, Côte d'Ivoire, Nigeria, and Togo; Luiselli et al., 2018). Similarly, more young and urban people stopped eating wild meat after the Ebola epidemic in West Africa (Funk et al., 2021). Diseases might reinforce the changing perceptions of eating habits through westernization, which regard wild meat consumption as socially unacceptable and backward (Luiselli et al., 2018).
Wild meat hunting is, on the one hand, a significant threat to wildlife and ecosystems, especially when unsustainable, but can also be an irreplaceable source of income and food security for many people (Ingram et al., 2021). Balancing these aspects is not straightforward. For example, calls to cease wild meat hunting, trade and consumption after the onset of COVID-19, might in fact cause negative impacts for people and ecosystems (Booth et al., 2021). Prohibition of use of wild meat could lead to food insecurity as well as to the conversion of ecosystems to agricultural land to produce alternative protein resources, causing further biodiversity loss and even increase emerging infectious disease risk (Booth et al., 2021; Borzée et al., 2020; Fa et al., 2021). Education of all stakeholders including conservationists, anthropologists, politicians, policymakers, and hunters of the complex interrelationship between wild meat, zoonotic diseases, conservation, and human food security is essential to find the optimal balance between biodiversity conservation and human needs. The lesson from the consumer behavior visiting Nigerian markets is that policymakers should recognize that there is now an opportunity to control wild meat sales and consumption for the benefit of human health and biodiversity conservation of (Fa et al., 2022). This can include additional awareness building through education campaigns. Such initiatives can be accompanied by other suitable intervention practices such as health controls in wild meat markets.

\section{ACKNOWLEDGMENTS}

The authors are grateful for the constructive comments of two anonymous reviewers. Julia E. Fa and Robert Nasi were supported by USAID as part of the Bushmeat Research Initiative of the CGIAR research program on Forests, Trees and Agroforestry. The other authors except Stephan M. Funk were supported during the various years of this long-term project by funds from IDECC, Mohamed Bin Zayed Species Conservation Fund, Sabin Family Foundation, Conservation International, Snamprogetti s.p.a., Associazione Centro Elis, Chelonian Research Foundation, and Turtle Conservation Fund.

\section{CONFLICT OF INTEREST}

The authors declare no conflict of interest.

\section{AUTHOR CONTRIBUTIONS}

Data collection: Stephanie N. Ajong, Edem A. Eniang, Daniele Dendi, Massimiliano Di Vittorio, Fabio Petrozzi, NioKing Amadi, Godfrey C. Akani, and Luca Luiselli. Project design and supervision: Luca Luiselli. Data analysis: Stephan M. Funk. Original manuscript; Stephan M. Funk, Julia E. Fa, and Luca Luiselli. Editing: all authors. 


\section{DATA AVAILABILITY STATEMENT}

Data are available upon request from authors Luca Luiselli (1.luiselli@ideccngo.org) and Stephan M. Funk (smf@natureheritage.org).

\section{ETHICS STATEMENT}

The survey procedures followed the ethical standards accepted by the British Sociological Association and did not involve any minors. Interviews were restricted to counting animal carcasses.

\section{ORCID}

\section{Stephan M. Funk @ https://orcid.org/0000-0001-7992-} 4115

Julia E. Fa (1) https://orcid.org/0000-0002-3611-8487 Daniele Dendi (D) https://orcid.org/0000-0003-1417-9091 Robert Nasi (1) https://orcid.org/0000-0001-9739-3135 Massimiliano Di Vittorio (D) https://orcid.org/0000-00017733-1551

Fabio Petrozzi (10) https://orcid.org/0000-0002-5114-3816 Luca Luiselli @ https://orcid.org/0000-0001-6878-2916

\section{REFERENCES}

Ajide, K. B., Ibrahim, R. L., \& Alimi, O. Y. (2020). Estimating the impacts of lockdown on Covid-19 cases in Nigeria. Transportation Research Interdisciplinary Perspectives, 7, 100217.

Akani, G. C., Amadi, N., Dendi, D., \& Luiselli, L. (2018). Do community metrics vary in reptile communities from Niger Delta forests subjected to slash-and-burn agricultural practices? African Journal of Ecology, 56, 1044-1048.

Akani, G. C., Dendi, D., \& Luiselli, L. (2015). Ebola virus effects on the bushmeat trade in West Africa. African Journal of Ecology, $53,613-615$.

BBC. (2021). Lockdown in Nigeria 2021 fit happun as coronavirus cases dey rise? See wetin we know. BBC News | Pidgin. Retrieved from https://www.bbc.com/pidgin/tori-55541814.

Bonwitt, J., Dawson, M., Kandeh, M., Ansumana, R., Sahr, F., Brown, H., \& Kelly, A. H. (2018). Unintended consequences of the 'bushmeat ban' in West Africa during the 2013-2016 Ebola virus disease epidemic. Social Science \& Medicine, 200, 166-173.

Booth, H., Clark, M., Milner-Gulland, E. J., Amponsah-Mensah, K., Pinassi Antunes, A., Brittain, S., Castilho, L. C., CamposSilva, J. V., de Araujo Lima Constantino, P., Li, Y., Mandoloma, L., Micah Nneji, L., Midoko Iponga, D., Mayo, B., McNamara, J., Sarobidy Rakotonarivo, O., Shi, J., Thibaut Kamogne Tagne, C., van Velden, J., \& Williams, D. R., (2021). Investigating the risks of removing wild meat from global food systems. Current Biology, 31, 1788-1797.e3.

Borzée, A., McNeely, J., Magellan, K., Miller, J. R. B., Porter, L., Dutta, T., Kadinjappalli, K. P., Sharma, S., Shahabuddin, G., Aprilinayati, F., Ryan, G. E., Hughes, A., Abd Mutalib, A. H., Wahab, A. Z. A., Bista, D., Chavanich, S. A., Chong, J. L., Gale, G. A., Ghaffari, H., ... Zhang, L. (2020). COVID-19 highlights the need for more effective wildlife trade legislation. Trends in Ecology \& Evolution, 35, 1052-1055.

Coad, L., Fa, J. E., Abernethy, K., van Vliet, N., Santamaria, C., Wilkie, D., Bizri, H. R. E., Ingram, D. J., Cawthorn, D.-M., \&
Nasi, R. (2019). Towards a sustainable, participatory and inclusive wild meat sector. CIFOR.

Cui, J., Li, F., \& Shi, Z.-L. (2019). Origin and evolution of pathogenic coronaviruses. Nature Reviews Microbiology, 17, 181-192.

Dixit, S., Ogundeji, Y. K., \& Onwujekwe, O. (2020). How well has Nigeria responded to COVID-19? Retrieved from https://www. brookings.edu/blog/future-development/2020/07/02/how-wellhas-nigeria-responded-to-covid-19/.

Eniang, E. A., Akani, G. C., Dendi, D., Fa, J., \& Luiselli, L. (2020). People's perceptions of crocodiles in Nigeria. Herpetological Journal, 30, 112-116.

Fa, J. E., Funk, S. M., \& Nasi, R. (2022). Hunting wildlife in the tropics and subtropics. Cambridge University Press.

Fa, J. E., Nasi, R., \& Funk, S. M. (2021). The COVID-19 pandemic endangers Africa's indigenous pygmy populations. EcoHealth, 1-3. https://doi.org/10.1007/s10393-021-01528-w

Fa, J. E., Seymour, S., Dupain, J., Amin, R., Albrechtsen, L., \& Macdonald, D. (2006). Getting to grips with the magnitude of exploitation: Bushmeat in the Cross-Sanaga rivers region, Nigeria and Cameroon. Biological Conservation, 129, 497-510.

Fa, J. E., Wright, J. H., Funk, S. M., Márquez, A. L., Olivero, J., Farfán, M. Á., Guio, F., Mayet, L., Malekani, D., Holo Louzolo, C., Mwinyihali, R., Wilkie, D. S., \& Wieland, M. (2019). Mapping the availability of bushmeat for consumption in Central African cities. Environmental Research Letters, 14, 094002.

FAO, CIRAD, CIFOR, WCS. (2020). Sustainable Wildlife Management (SWM) Programme Policy Brief-Build back better in a post COVID-19 world: Reducing future wildlife-borne spillover of disease to humans. Rome, FAO. https://doi.org/10.4060/ cb1490en.

Funk, S. M., Fa, J. E., Ajong, S. N., Eniang, E. A., Dendi, D., Di Vittorio, M., Petrozzi, F., Amadi, N. K., Akani, G. C., \& Luiselli, L. (2021). Pre- and post-Ebola outbreak trends in wild meat trade in West Africa. Biological Conservation, 255, 109024.

Guan, Y., Zheng, B. J., He, Y. Q., Liu, X. L., Zhuang, Z. X., Cheung, C. L., Luo, S. W., Li, P. H., Zhang, L. J., \& Guan, Y. J. (2003). Isolation and characterization of viruses related to the SARS coronavirus from animals in southern China. Science, 302, 276-278.

Ingram, D. J., Coad, L., Milner-Gulland, E. J., Parry, L., Wilkie, D., Bakarr, M. I., Benítez-López, A., Bennett, E. L., Bodmer, R., Cowlishaw, G., el Bizri, H. R., Eves, H. E., Fa, J. E., Golden, C. D., Iponga, D. M., Minh, N. V., Morcatty, T. Q., Mwinyihali, R., Nasi, R., ... Abernethy, K. (2021). Wild meat is still on the menu: Progress in wild meat research, policy, and practice from 2002 to 2020. Annual Review of Environment and Resources, 46, 254. https://doi.org/10.1146/annurev-environ041020-063132

Jones, K. E., Patel, N. G., Levy, M. A., Storeygard, A., Balk, D., Gittleman, J. L., \& Daszak, P. (2008). Global trends in emerging infectious diseases. Nature, 451, 990-993.

Karesh, W. B., \& Noble, E. (2009). The bushmeat trade: Increased opportunities for transmission of zoonotic disease. Mount Sinai Journal of Medicine, 76, 429-434.

Lu, H., Stratton, C. W., \& Tang, Y. (2020). Outbreak of pneumonia of unknown etiology in Wuhan, China: The mystery and the miracle. Journal of Medical Virology, 92, 401-402.

Luiselli, L., Akani, G. C., Petrozzi, F., \& Eniang, E. A. (2016). Threatened tortoises (genus Kinixys) are confined to small 
portions of forest even inside wide protected reserves in The Niger Delta, Nigeria. African Journal of Ecology, 54, 256-260.

Luiselli, L., Petrozzi, F., \& Akani, G. C. (2013). Long-term comparison reveals trends in turtle trade in bushmeat markets of southern Nigeria. Herpetozoa, 26, 57-64.

Luiselli, L., Hema, E. M., Segniagbeto, G. H., Ouattara, V., Eniang, E. A., Parfait, G., Akani, G. C., Sirima, D., Fakae, B. B., Dendi, D., \& Fa, J. E. (2018). Bushmeat consumption in large urban centres in West Africa. Oryx, 54, 1-4.

McNamara, J., Robinson, E. J. Z., Abernethy, K., Midoko Iponga, D., Sackey, H. N. K., Wright, J. H., \& MilnerGulland, E. (2020). COVID-19, systemic crisis, and possible implications for the wild meat trade in sub-Saharan Africa. Environmental and Resource Economics. 76, 1045-1066. https:// doi.org/10.1007/s10640-020-00474-5

Meseko, C., Shittu, I., \& Adedeji, A. (2020). The bush meat trade thrives in Nigeria despite anxiety over coronavirus. Transactions of the Royal Society of Tropical Medicine and Hygiene, 114, 639-641.

Owhonda, G., Maduka, O., Nwadiuto, I., Tobin-West, C., Azi, C., Ojimah, C., Alasia, D., Olofinuka, A.-M., Agala, V., Nwolim Paul, J., Nria, D., Okafor, C., Ndekwu, I., Opara, C., \& Newsom, C. (2020). Awareness, perception and practice of COVID 19 prevention among residents of a state in the southsouth region of Nigeria: Implications for public health control efforts. medRxiv preprint. Public and Global Health. Retrieved from http://medrxiv.org/lookup/doi/10.1101/2020.10.11.20210864.

Petrozzi, F., Amori, G., Franco, D., Gaubert, P., Pacini, N., Eniang, E. A., Akani, G. C., Politano, E., \& Luiselli, L. (2016). Ecology of the bushmeat trade in West and Central Africa. Tropical Ecology, 57, 545-557.

Reading, C. J., Luiselli, L. M., Akani, G. C., Bonnet, X., Amori, G., Ballouard, J. M., Filippi, E., Naulleau, G., Pearson, D., \&
Rugiero, L. (2010). Are snake populations in widespread decline? Biology Letters, 6, 777-780.

Taylor, G., Scharlemann, J. P. W., Rowcliffe, M., Kümpel, N., Harfoot, M. B. J., Fa, J. E., Melisch, R., Milner-Gulland, E. J., Bhagwat, S., Abernethy, K. A., Ajonina, A. S., Albrechtsen, L., Allebone-Webb, S., Brown, E., Brugiere, D., Clark, C., Colell, M., Cowlishaw, G., Crookes, D., ... Coad, L. M. (2015). Synthesising bushmeat research effort in West and Central Africa: A new regional database. Biological Conservation, 181, 199-205.

Tu, C., Crameri, G., Kong, X., Chen, J., Sun, Y., Yu, M., Xiang, H., Xia, X., Liu, S., Ren, T., Yu, Y., Eaton, B. T., Xuan, H., \& Wang, L. F. (2004). Antibodies to SARS coronavirus in civets. Emerging Infectious Diseases, 10, 2244-2248.

UNEP, International Livestock Research Institute. (2020). Preventing the next pandemic- zoonotic diseases and how to break the chain of transmission. UNEP.

WILDAID USA. (2021). Understanding urban consumption of bushmeat in Nigeria. WILDAID Retrieved from https://wildaid. org/wp-content/uploads/2021/01/Nigeria-BushmeatConsumption-Survey-Report.pdf

How to cite this article: Funk, S. M., Fa, J. E., Ajong, S. N., Eniang, E. A., Dendi, D., Nasi, R., Di Vittorio, M., Petrozzi, F., Amadi, N. K., Akani, G. C., \& Luiselli, L. (2021). Impact of COVID-19 on wild meat trade in Nigerian markets. Conservation Science and Practice, e599. https://doi.org/10.1111/ csp2.599 